\title{
PELATIHAN TENTANG GAYA HIDUP SEHAT PENDERITA DIABETES MELLITUS PADA KELOMPOK PKK DI KELURAHAN KAUMAN KOTA MALANG
}

\author{
Ellyvina Setya Dhini ${ }^{1)}$, Wibowo $^{1)}$, Mamiek Wilastri'1) \\ 1)Program Studi S1 Farmasi, Sekolah Tinggi Ilmu Kesehatan Panti Waluya, Malang, Jawa Timur, Indonesia \\ Corresponding author : Ellyvina Setya Dhini \\ E-mail : ellyvinaenmala@gmail.com
}

Diterima 29 November 2021, Direvisi 08 Desember 2021, Disetujui 09 Desember 2021

\begin{abstract}
ABSTRAK
Angka prevalensi Diabetes Mellitus (DM) di Jawa Timur lebih tinggi dibandingkan dengan daerah lain di Indonesia. Hal ini tergambar di kota Malang Jawa Timur tepatnya di Kelurahan Kauman yang berdomisili ditengah kota diketahui jumlah penderita DM cukup tinggi sedangkan pengetahuan warganya dalam pemahaman gaya hidup sehat penderita DM (diabetisi) masih kurang. Tujuan dari pengabdian kepada masyarakat (PKM) ini adalah memberikan pengetahuan tentang gaya hidup sehat diabetisi, dengan metode melakukan pelatihan melalui media zoom kepada kelompok PKK Kelurahan Kauman Malang. Dalam pelatihan tersebut juga dilakukan pre dan post test serta pengisian kuisioner menggunakan google form oleh peserta pelatihan. Hasil dari pre dan post test serta kuisioner dianalisa sehingga diperoleh persentase untuk mengetahui gambaran pemahaman dan kemampuan peserta dalam memberikan informasi dan melaksanakan gaya hidup sehat diabetisi kepada keluarga/ tetangga disekitarnya. Dari hasil pre dan post test diperoleh gambaran terjadinya peningkatan pengetahuan tentang gaya hidup sehat diabetisi dari rata rata $46 \%$ menjadi $98,8 \%$. Peserta yang memahami dan menyatakan bahwa gaya hidup sehat diabetisi memungkinkan untuk diterapkan dalam kehidupan sehari hari sebanyak $94 \%$. Seluruh peserta $(100 \%)$ bersedia menerangkan, menerapkan, melaksanakan dan telah terjadi perubahan gaya hidup sehat diabetisi kepada keluarga dan orang - orang dilingkungan sekitarnya. Hasil dari pelatihan ini memberikan harapan tejadinya perbaikan kualitas hidup diabetisi di Kelurahan Kauman kota Malang.
\end{abstract}

Kata kunci : gaya hidup; diabetes mellitus; kelompok PKK

\begin{abstract}
Prevalence of Diabetes Mellitus (DM) in East Java is higher than other regions in Indonesia. That illustrated in the city of Malang, East Java, precisely in the Kauman Village, which is domiciled in the middle of the city, it is known that number of DM sufferers is quite high, while the knowledge of citizens in understanding of healthy lifestyle of DM patients) is still lacking. The purpose of this community service (PKM) is to provide knowledge about healthy lifestyles with diabetes, with the method of conducting training through zoom media to the PKK group in Kauman Malang Village. In the training, pre and post tests were also carried out as well as filling out questionnaires using google forms by the trainees to get a picture of the participants' understanding and ability in providing information and implementing a healthy lifestyle with diabetes to their families/neighbors around them. The results of pre and post tests, it was obtained there was an increase in knowledge about a healthy lifestyle with diabetes from an average of $46 \%$ to $98.8 \%$. Participants who understand and state that a healthy lifestyle with diabetes allows it to be applied in daily life as many as $94 \%$. All participants $(100 \%)$ are willing to explain, implementation and there have been changes to a healthy lifestyle with diabetes to their families and people in the surrounding environment. The results of this training provide hope for an improvement in the quality of life for people with diabetes in Kauman Village, Malang City.
\end{abstract}

Keywords : lifestyle; diabetes mellitus; PKK group

\section{PENDAHULUAN}

Angka prevalensi Diabetes Mellitus (DM) di Jawa Timur meningkat cukup signifikan bahkan lebih tinggi dibandingkan dengan daerah lain di seluruh Indonesia. Jumlah penderita DM di Indonesia terbesar pada rentang usia $55-74$ tahun, wanita lebih banyak dari pada pria dan lebih banyak tinggal di perkotaan disbanding pedesaan (Kemenkes RI, 2018). Diabetes Mellitus disebut dengan the silent killer karena dapat menimbulkan komplikasi pada organ tubuh dan menimbulkan berbagai macam keluhan (Fatimah, 2015). Salah satu faktor yang mempengaruhi 
terjadinya DM adalah pola makan yang tidak sehat dimana pasien DM (diabetisi) cenderung terus menerus mengkonsumsi karbohidrat dan makanan sumber glukosa secara berlebihan (Khairani, 2019). Untuk itu diperlukan pengaturan diet dalam mengkonsumsi makanan yang harus diterapkan dalam kebiasaan makan sehari-hari. Kepatuhan dalam mengatur pola makan dipengaruhi oleh pendidikan, akomodasi, perubahan model terapi, modifikasi faktor lingkungan dan sosial, serta interaksi profesional tenaga kesehatan dengan pasien(Phitri \& Widiyaningsih, 2013).

Kelurahan Kauman yang terletak di pusat kota Malang, tidak menjamin pengetahuan warganya dalam pemahaman gaya hidup sehat penderita diabetes (diabetisi). Hal tersebut tercermin dari hasil kuisioner yang disebarkan kepada kelompok PKK Kelurahan Kauman yang menunjukkan bahwa sebagian besar anggota meminta dilakukan pelatihan tentang gaya hidup sehat diabetisi. Kepedulian kelompok PKK ini dapat dipahami mengingat jumlah diabetisi di kelurahan Kauman cukup tinggi yang diperkirakan akibat gaya hidup yang tidak sehat.kata kunci yang ditulis dengan ukuran huruf 10 point, untuk menunjukkan subyek permasalahan artikel anda, sekaligus untuk keperluan pengindeksan.

\section{METODE}

Metode yang digunakan dalam PKM ini adalah memberikan pelatihan tentang Gaya Hidup Sehat Diabetisi kepada kelompok PKK Kelurahan Kauman diikuti oleh ketua PKK yang mewakili masing masing RW dilakukan pada bulan Agustus 2021. Pelaksanan pelatihan dibagi menjadi 3 tahap dalam waktu 1 minggu dengan menggunakan media Zoom . Tahap pertama (1) diawali dengan pre test menggunakan google form dilanjutkan pemberian materi dan diikuti pengisian kuisioner untuk mengetahui pemahaman peserta terhadap materi yang telah diberikan. Tahap kedua (2) dilakukan pemberian materi kembali dan ditutup dengan pengisisan kuisioner untuk mengetahui pelaksanaan gaya hidup sehat. Tahap ketiga (3) merupakan evaluasi dari rangkaian pelatihan, dilakukan diskusi dengan peserta tentang pemahaman dan pelaksanaan gaya hidup sehat diabetisi, pada tahap ini juga dilakukan post test.. Hasil dari kuisioner tersebut hasil tersebut dianalisa untuk diperoleh persentase sehingga diperoleh gambaran terhadap pemahaman dan pelaksanaan Gaya Hidup Sehat Diabetisi oleh kelompok PKK Kelurahan Kauman Malang.

\section{HASIL DAN PEMBAHASAN}

Peserta pelatihan berjumlah 18 orang dan seluruhnya berjenis kelamin perempuan dengan rentang usia $31-40$ tahun sebanyak $11,11 \%$, usia $41-50$ tahun $44,44 \%$ dan 51 60 tahun $44,44 \%$. Seluruh peserta merupakan ketua PKK RW Kelurahan Kauman Malang sehingga diharapkan gaya hidup sehat dapat diterangkan dan diterapkan kepada keluarga, tetangga atau anggota PKK di RW masing masing.

Hasil rata rata pre test $(46 \%)$ dan post test $(98,8 \%)$ menunjukkan peningkatan yang berarti, hal ini menunjukkan bahwa terjadi peningkatan pengetahuan tentang gaya hidup sehat pada peserta yang hasilnya dapat dilihat pada tabel dibawah ini

Tabel 1. Hasil Pre dan Post Test

\begin{tabular}{|c|c|c|c|c|}
\hline \multirow{2}{*}{ Kuisioner I } & \multicolumn{2}{|c|}{ Pre test (\%) } & \multicolumn{2}{|c|}{ Post test (\%) } \\
\hline & $\mathrm{Ya}$ & Tidak & $\mathrm{Ya}$ & Tidak \\
\hline $\begin{array}{c}\text { Paham } \\
\text { makanan yang } \\
\text { mengandung } \\
\text { karbohidrat } \\
\text { berlebih bisa } \\
\text { meningkatkan } \\
\text { kadar gula } \\
\text { dalam darah }\end{array}$ & 60 & 40 & 100 & 0 \\
\hline $\begin{array}{l}\text { Tahu bahwa } \\
\text { diabetisi } \\
\text { membutuhkan } \\
\text { olah raga }\end{array}$ & 40 & 60 & 100 & 0 \\
\hline $\begin{array}{c}\text { Tahu bahwa } \\
\text { diabetisi harus } \\
\text { minum obat } \\
\text { secara teratur } \\
\text { dan terus } \\
\text { menerus }\end{array}$ & 40 & 60 & 94 & 6 \\
\hline $\begin{array}{c}\text { Tahu bahwa } \\
\text { penyakit } \\
\text { Diabetes } \\
\text { Mellitus dapat } \\
\text { menyebabkan } \\
\text { komplikasi/ } \\
\text { kerusakan } \\
\text { organ } \\
\end{array}$ & 50 & 50 & 100 & 0 \\
\hline $\begin{array}{l}\text { Tahu gaya } \\
\text { hidup sehat } \\
\text { dapat } \\
\text { mencegah } \\
\text { terjadinya } \\
\text { komplikasi/ } \\
\text { kerusakan } \\
\text { organ }\end{array}$ & 40 & 60 & 100 & 0 \\
\hline
\end{tabular}

Sebagian besar peserta menyatakan bersedia menerangkan dan menerapkan gaya hidup sehat diabetisi kepada keluarga dan orang disekitarnya, hal ini tergambar dari hasil pengisian kuisioner II pada tabel dibawah ini 
Tabel 2. Kesediaan Menerangkan Dan Menerapkan Gaya Hidup Sehat

\begin{tabular}{ccc}
\hline Kuisioner II & Ya & $\begin{array}{c}\text { Tidak } \\
\text { (\%) }\end{array}$ \\
\hline $\begin{array}{c}\text { Apakah memahami materi } \\
\text { pelatihan? }\end{array}$ & 94 & 6 \\
\hline $\begin{array}{c}\text { Apakah memungkinkan } \\
\text { menerapkan gaya hidup } \\
\text { sehat kepada diabetisi } \\
\text { dalam kehidupan sehari } \\
\text { hari? }\end{array}$ & 94 & 6 \\
\hline $\begin{array}{c}\text { Apakah bersedia } \\
\text { menerapkan gaya hidup } \\
\text { sehat kepada keluarga } \\
\text { terdekat yang menderita } \\
\text { DM? }\end{array}$ & & \\
\hline $\begin{array}{c}\text { Apakah bersedia } \\
\text { menerangkan gaya hidup }\end{array}$ & 100 & 0 \\
sehat kepada orang - \\
orang disekitar (kelompok \\
PKK RT/RW/ tetangga)?
\end{tabular}

Dalam pelatihan ini juga diberikan kuisioner tentang pelaksanaan gaya hidup sehat diabetisi dengan hasil pada tabel 3

Tabel 3. Pelaksanaan Gaya Hidup Sehat Diabetisi

\begin{tabular}{ccc}
\hline Kuisioner III & Ya $\begin{array}{c}\text { Tidak } \\
\text { (\%) }\end{array}$ \\
\hline $\begin{array}{c}\text { Apakah telah menerapkan } \\
\text { gaya hidup sehat diabetisi } \\
\text { kepada keluarga terdekat }\end{array}$ & 100 & 0 \\
\hline $\begin{array}{c}\text { Apakah telah menerangkan } \\
\text { gaya hidup sehat kepada } \\
\text { orang - orang disekitar } \\
\text { anda }\end{array}$ & 94 & 6 \\
\hline $\begin{array}{c}\text { Apakah keluarga bersedia } \\
\text { melakukan gaya hidup } \\
\text { sehat? }\end{array}$ & 100 & 0 \\
\hline $\begin{array}{c}\text { Apakah ada perubahan } \\
\text { gaya hidup setelah } \\
\text { diterangkan/ diterapkan } \\
\text { gaya hidup sehat pada } \\
\text { keluarga/ orang disekitar } \\
\text { anda? }\end{array}$ & 94 & 6 \\
\hline
\end{tabular}

Pelatihan tentang gaya hidup sehat diabetisi pada kelompok PKK di kelurahan Kauman kota Malang telah dilakukan dalam 3 tahap memberikan gambaran terjadi peningkatan pengetahuan tentang gaya hidup diabetisi. Gambaran tersebut menunjukkan hasil yang sejalan dengan penelitian yang telah dilakukan oleh Bertaliana dkk (2016) yang menunjukkan terdapat hubungan antara pengetahuan, motivasi pasien serta dukungan keluarga dengan kepatuhan diet pada pasien DM (Bertalina \& Purnama, 2016). Demikian pula hasil dari penelitian yang dilakukan oleh Fatma dkk (2015) menunjukkan bahwa terdapat hubungan antara dukungan keluarga dengan kualitas hidup pasien (Nuraisyah et al., 2017). Sedangkan penelitian yang dilakukan di RS.Tingkat II dr. Soepraoen (2017) diperoleh hasil bahwa terdapat hubungan antara pengetahuan tentang diabetes mellitus dengan gaya hidup pasien diabetes mellitus (Jasmani et al., 2016).

\section{SIMPULAN DAN SARAN}

Hasil dari pelatihan ini menunjukkan peningkatan pengetahuan dan memberikan harapan tejadinya perbaikan kualitas hidup diabetisi di kelurahan Kauman kota Malang. Disarankan untuk melanjutkan pemantauan pelaksanaan gaya hidup sehat diabetisi agar perbaikan kualitas hidup diabetisi di Kelurahan Kauman Kota Malang dapat dipertahankan dan ditingkatkan .

\section{UCAPAN TERIMAKASIH}

Ucapan terima kasih kami tujukan kepada STIKes Panti Waluya Malang sebagai penyandang dana tunggal atas terlaksananya Pengabdian Kepada Masyarakat Kelompok PKK Kelurahan Kauman Kota Malang

\section{DAFTAR RUJUKAN}

Bertalina, B., \& Purnama, P. (2016). Hubungan Lama Sakit, Pasien Diabetes Mellitus. Jurnal Kesehatan, 7(2), 329.

Fatimah, R. N. (2015). DIABETES MELITUS TIPE 2. Journal Majority, 5.

Jasmani, Ri, T., \& Hiantoro. (2016). Edukasi dan kadar glukosa darah pada pasien diabetes. Jurnal Keperawatan, XII(1), 140148.

Kemenkes RI. (2018). Hasil Utama Riset Kesehatan Dasar (RISKESDAS). In Badan Penelitian dan Pengembangan Kesehatan RI. Kemenkes RI. https://doi.org/10.1088/17518113/44/8/085201

Khairani. (2019). Hari Diabetes Sedunia Tahun 2018. In Pusat Data dan Informasi Kementrian Kesehatan RI.

Nuraisyah, F., Kusnanto, H., \& Rahayujati, T. B. (2017). Dukungan keluarga dan kualitas hidup pasien diabetes mellitus. Berita Kedokteran Masyarakat, 33(1), 25. https://doi.org/10.22146/bkm.7886

Phitri, H. E., \& Widiyaningsih. (2013). Hubungan Antara Pengetahuan Dan Sikap Penderita Diabetes Mellitus Dengan Kepatuhan Diet Diabetes Mellitus Di Rsud Am . Parikesit Kalimantan Timur. Jurnal Keperawatan Medikal Bedah, 1(1), 58-74. 